\title{
Seasonal variations in concentration and lability of dissolved organic carbon in Tokyo Bay
}

\author{
A. Kubo ${ }^{1}$, M. Yamamoto-Kawai ${ }^{2}$, and J. Kanda ${ }^{1}$ \\ ${ }^{1}$ Department of Ocean Sciences, Tokyo University of Marine Science and Technology, 4-5-7 Konan, Minato-ku, Tokyo, \\ 108-8477, Japan \\ ${ }^{2}$ Center for Advanced Science and Technology, Tokyo University of Marine Science and Technology, 4-5-7 Konan, \\ Minato-ku, Tokyo, 108-8477, Japan
}

Correspondence to: A. Kubo (kuboatsushi0412@gmail.com)

Received: 9 June 2014 - Published in Biogeosciences Discuss.: 1 July 2014

Revised: 7 November 2014 - Accepted: 24 November 2014 - Published: 15 January 2015

\begin{abstract}
Concentrations of recalcitrant and bioavailable dissolved organic carbon (DOC) and their seasonal variations were investigated at three stations in Tokyo Bay, Japan, and in two freshwater sources flowing into the bay. On average, recalcitrant DOC (RDOC), as a remnant of DOC after 150 days of bottle incubation, accounted for $78 \%$ of the total DOC in Shibaura sewage treatment plant (STP) effluent, $67 \%$ in the upper Arakawa River water, $66 \%$ in the lower Arakawa River water, and $78 \%$ in surface bay water. Bioavailable DOC (BDOC) concentrations, defined as DOC minus RDOC, were lower than RDOC at all stations. In freshwater environments, RDOC concentrations were almost constant throughout the year. In the bay, RDOC was higher during spring and summer than in autumn and winter because of freshwater input and biological production. The relative concentration of RDOC in the bay derived from phytoplankton, terrestrial, and open-oceanic waters was estimated to be 8-10, 21-32, and 59-69\%, respectively, based on multiple regression analysis of RDOC, salinity, and chl $a$. In addition, comparison with previous data from 1972 revealed that concentrations of RDOC and BDOC have decreased by 33 and $74 \%$ at freshwater sites and 39 and $76 \%$ in Tokyo Bay, while the ratio of RDOC to DOC has increased. The change in DOC concentration and composition was probably due to increased amounts of STP effluent entering the system. Tokyo Bay exported mostly RDOC to the open ocean because of the remineralization of $\mathrm{BDOC}$.
\end{abstract}

\section{Introduction}

The dissolved organic carbon (DOC) pool is the largest organic carbon reservoir in the ocean and contains $662 \mathrm{Pg}$ of carbon, which is roughly equivalent to that stored in the atmosphere in the form of carbon dioxide (Hansell et al., 2009). In open oceans, DOC production is ultimately constrained by primary production (e.g., Carlson, 2002). In coastal waters, DOC consists of diverse mixtures of carbon with varying timescales of lability formed by primary production and materials of terrestrial origin. Riverine DOC export to the open ocean has been estimated to range from 0.21 to $0.25 \mathrm{PgC} \mathrm{yr}^{-1}$ (Meybeck, 1993; Ludwig et al., 1996; Hedges et al., 1997; Cauwet, 2002), without considering loss or gain of DOC in coastal waters. Coastal waters are typically considered passive conduits in regional and global carbon budgets (Cole et al., 2007; Aufdenkampe et al., 2011; Regnier et al., 2013). However, degradation of terrestrial DOC and biological production of DOC in coastal regions can significantly modify the flux of DOC to the open ocean. Dai et al. (2012) recently reported that riverine DOC export to the open ocean would be reduced to $0.17 \mathrm{PgC} \mathrm{yr}^{-1}$ if $10 \%$ was degraded in coastal waters. However, their assumption of $10 \%$ was based on the results of only a few bottle incubation experiments (Amon and Benner, 1996; Raymond and Bauer, 2000; Moran et al., 1999). Therefore, to better understand DOC export to the open ocean, experimental data describing DOC lability, preferably from different environmental locations and different seasons, are needed. 
In this study, we measured seasonal variations in the concentration and lability of DOC in Tokyo Bay, Japan, to evaluate the significance of DOC degradation to the carbon budget in coastal waters and carbon export to the open ocean. The bay is semi-enclosed, with an area of about $922 \mathrm{~km}^{2}$ and a mean water depth of $19 \mathrm{~m}$. The residence time of water in the bay is estimated to be about 50 days (Takada et al., 1992). The bay is located in central Japan and surrounded by metropolitan areas, with a total population of about 29 million. Tokyo Bay represents typical highly urbanized coastal waters, which are rapidly expanding worldwide (Nellemann et al., 2008). We also compared our results with those obtained by Ogura (1975), who carried out an investigation of Tokyo Bay in the 1970s and found that DOC in coastal waters could be divided into bioavailable DOC (BDOC) and recalcitrant DOC (RDOC). Owing to his investigation, BDOC and RDOC data from 1972 are available for Tokyo Bay.

\section{Materials and methods}

Freshwater samples were collected two and eight times from the upper and lower Arakawa River, respectively, and five times from effluent of the Shibaura sewage treatment plant (STP; Fig. 1) between December 2011 and October 2013. Freshwater samples were collected using a bucket, transferred into $\mathrm{HCl}$ acid-washed $1 \mathrm{~L}$ polyethylene bottles, and kept in the dark until being processed in the laboratory. The bucket and sample bottles were rinsed three times with sample water before being filled. Within $2 \mathrm{~h}$ of sample collection, the freshwater samples were carried back to the laboratory. DOC and the degradation experiment samples were filtered immediately after arrival in the laboratory through $\mathrm{GF} / \mathrm{F}$ filters (nominal pore size $0.7 \mu \mathrm{m}$ ) that had been precombusted at $450^{\circ} \mathrm{C}$ for $3 \mathrm{~h}$. Surface seawater of Tokyo Bay was collected monthly in $8 \mathrm{~L}$ Niskin bottles mounted on a conductivity-temperature-depth (CTD) rosette on the R/V Seiyo-maru of Tokyo University of Marine Science and Technology at three stations from January 2012 to December 2012 (Fig. 1). Within $1 \mathrm{~h}$ of sample collection, DOC and the degradation experiment samples were filtered through precombusted GF/F filters on board. Then, samples were kept in the dark and carried back to the laboratory within $4 \mathrm{~h}$. We assumed that GF/F filters allow the passage of a significant fraction of free-living bacteria into DOC samples (e.g., Bauer and Bianchi, 2011). In addition, Tranvik and Höfle (1987) investigated the interactions between bacterial assemblages and DOC consumption using batch cultures and found that the DOC bioavailability was independent of the inoculum. Tanaka et al. (2011) also showed that the mineralization rate of the BDOC fraction in a coral reef was not different from natural waters and waters filtrated by GF/F; nevertheless, the initial bacterial abundance in the incubated waters filtrated by GF/F was about $30-50 \%$ of bacteria abundance in natural waters. Therefore, we did not add the microbial community. We also did not add nutrients for the degradation experiment because we assumed nutrients were not limiting microbial growth (see Sect. 3.1). Degradation experiment samples were then transferred to $600 \mathrm{~mL}$ amber glass bottles and stored at room temperature $\left(20^{\circ} \mathrm{C}\right)$ in total darkness until analysis. The $100 \mathrm{~mL}$ headspace in each glass bottle contains about $900 \mu \mathrm{mol}$ oxygen. The highest initial DOC concentration in this study was $430 \mu \mathrm{molL}^{-1}$ (Table 1). If we assume that $1 \mathrm{~mol}$ of oxygen is consumed when $1 \mathrm{~mol}$ of organic carbon is mineralized into $\mathrm{CO}_{2}$, the oxygen in the headspace should have provided sufficient oxygen supply for heterotrophic decomposition by bacteria. The degradation experiments were conducted based on a total of seven incubations $(0,5,10,20,50,100$, and 150 days) per field sampling event. After incubation, samples were dispensed into glass vials that had been prewashed with $\mathrm{HCl}$ and pure water (Milli-Q water, Millipore Corp., Bedford, MA, USA) and then precombusted. Freshwater samples were preserved with $6 \mathrm{molL}^{-1} \mathrm{HCl}$ at a concentration corresponding to $1 \%$ of the sample volume, then stored in a refrigerator $\left(5^{\circ} \mathrm{C}\right)$. Tokyo Bay samples were frozen $\left(-25^{\circ} \mathrm{C}\right)$ without adding $\mathrm{HCl}$. DOC samples were measured at least in triplicate with a total organic carbon (TOC) analyzer (TOC- $\mathrm{V}_{\mathrm{CSH}}$, Shimadzu, Kyoto, Japan). Potassium hydrogen phthalate (Wako Pure Industries, Osaka, Japan) was used as a standard for the measurement of DOC. DOC blank, including pure water, instrument blank, and any carbon derived from the vials, was about $3 \mu \mathrm{molL}^{-1}$ in total.

RDOC was here defined as the concentration of DOC remaining at 150 days, and BDOC was obtained by subtracting RDOC from the initial DOC (Lønborg et al., 2009). The degradation rate of DOC was described by a first-order exponential decay model with a constant RDOC pool:

$\mathrm{DOC}(t)=\mathrm{BDOC} \cdot \exp (-k \cdot t)+\mathrm{RDOC}$,

where $\mathrm{DOC}(t)$ is the amount of DOC remaining at time $t$ (day), $k$ is the degradation rate constant $\left(\mathrm{day}^{-1}\right)$, and RDOC is the remaining DOC pool after 150 days of incubation. BDOC is the bioavailable DOC $\left(\mu \mathrm{molL}^{-1}\right)$ at the beginning of incubation and practically equals the subtraction of RDOC from initial DOC. Using BDOC and RDOC concentrations, $k$ can be estimated by fitting the observed $\operatorname{DOC}(t)$ values to Eq. (1) using Matlab 2012a. For comparison with the results reported by Lønborg and Álvarez-Salgado (2012), we used the following equation to normalize the degradation rate to the rate at $15^{\circ} \mathrm{C}$ :

$k\left(15^{\circ} \mathrm{C}\right)=k(T) \cdot\left(Q_{10}\right)^{\frac{T-15}{10}}$,

where $k\left(15^{\circ} \mathrm{C}\right)$ and $k(\mathrm{~T})$ are the degradation rate constants at $15^{\circ} \mathrm{C}$ and $T^{\circ} \mathrm{C}\left(20^{\circ} \mathrm{C}\right.$ for our experiment). $Q_{10}$ is the temperature coefficient. In this study, we used a value of 2.2, based on Lønborg and Álvarez-Salgado (2012).

Temperature and salinity were measured in the field using a YSI EC 300 (YSI/Nanotech Inc., Yellow Springs, 
Table 1. Temperature $\left({ }^{\circ} \mathrm{C}\right)$, salinity, chl $a$ concentrations $\left(\mu \mathrm{L} \mathrm{L}^{-1}\right)$, DOC concentrations $\left(\mu \mathrm{mol} \mathrm{L}^{-1}\right) \pm$ standard deviation, and POC concentrations $\left(\mu \mathrm{mol} \mathrm{L}{ }^{-1}\right)$ at the upper Arakawa River (upper AR), the lower Arakawa River (lower AR), and Shibaura STP stations.

\begin{tabular}{llrrrrr}
\hline Station & Date & Temp. & Sal. & chl $a$ & DOC & POC \\
\hline Upper AR & Apr 2013 & 10.9 & 0.0 & 0.2 & $33 \pm 0$ & 13 \\
Upper AR & Oct 2013 & 17.4 & 0.0 & 0.2 & $42 \pm 1$ & 7 \\
\hline Lower AR & Dec 2011 & 12.1 & 0.6 & 2.0 & $247 \pm 4$ & 178 \\
Lower AR & Jan 2012 & 7.0 & 0.2 & 7.6 & $290 \pm 5$ & 145 \\
Lower AR & Feb 2012 & 7.2 & 0.2 & 49.3 & $355 \pm 3$ & 313 \\
Lower AR & May 2012 & 23.6 & 0.2 & 33.9 & $205 \pm 1$ & 168 \\
Lower AR & Jul 2012 & 24.2 & 0.2 & 1.5 & $213 \pm 2$ & 84 \\
Lower AR & Aug 2012 & 23.9 & 0.0 & 1.2 & $185 \pm 2$ & 59 \\
Lower AR & Nov 2012 & 17.4 & 0.2 & 2.0 & $236 \pm 2$ & 63 \\
Lower AR & Dec 2012 & 11.8 & 0.2 & 10.7 & $155 \pm 1$ & 76 \\
\hline Shibaura STP* & Jan 2012 & 14.9 & 0.4 & 0.9 & $387 \pm 2$ & 191 \\
Shibaura STP* & Feb 2012 & 17.2 & 1.2 & 0.1 & $305 \pm 3$ & 79 \\
Shibaura STP & May 2012 & 27.6 & 2.9 & 3.7 & $430 \pm 4$ & 71 \\
Shibaura STP & Jul 2012 & 27.9 & 1.9 & 0.5 & $366 \pm 3$ & 38 \\
Shibaura STP & Aug 2012 & 27.7 & 1.9 & 2.2 & $292 \pm 2$ & 48 \\
Shibaura STP & Nov 2012 & 20.5 & 4.0 & 0.3 & $341 \pm 3$ & 76 \\
Shibaura STP & Dec 2012 & 17.2 & 0.4 & 1.2 & $366 \pm 3$ & 83 \\
\hline
\end{tabular}

* Sampling for water properties only (no degradation experiment)

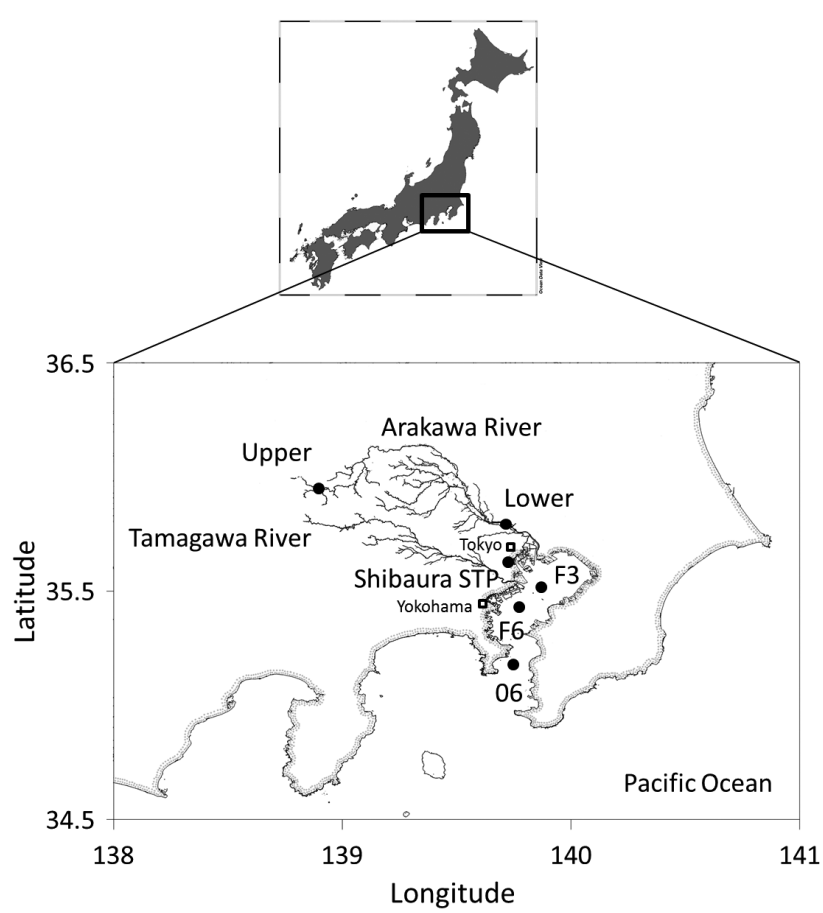

Figure 1. Map of Tokyo Bay. Locations of sampling sites are indicated by black circles.

OH, USA) at freshwater sites and a CTD (Falmouth Scientific Inc., Bourne, MA, USA) for sites in the bay. Water samples for chlorophyll $a(\mathrm{chl} a)$ measurement were filtered through precombusted $\left(450^{\circ} \mathrm{C}, 3 \mathrm{~h}\right) \mathrm{GF} / \mathrm{F}$ filters. Af- ter filtration, chlorophyllous pigments were extracted using $\mathrm{N}, \mathrm{N}$-dimethylformamide, and the concentrations of chl $a$ were determined by the fluorometric method (Suzuki and Ishimaru, 1990; fluorometer used: TD-700, Turner Designs, Sunnyvale, CA, USA). Samples for particulate organic carbon $(\mathrm{POC})$ were filtered through precombusted $\left(450^{\circ} \mathrm{C}, 3 \mathrm{~h}\right)$ $\mathrm{GF} / \mathrm{F}$ filters, after which the filters were stored at $-80^{\circ} \mathrm{C}$ until analysis. The samples for POC analyses were dried at $60^{\circ} \mathrm{C}$ and acidified with vapor at $12 \mathrm{~mol} \mathrm{~L}^{-1} \mathrm{HCl}$ to remove carbonate before analysis. POCs were measured using an isotope ratio mass spectrometer (Hydra 20-20, SerCon Ltd., Crewe, UK) coupled to an elemental analyzer (ANCA-GSL, SerCon Ltd., Crewe, UK).

\section{Results and discussion}

\subsection{Nutrient conditions in Tokyo Bay}

Nutrient concentrations in freshwater and Tokyo Bay sites were high throughout the year (Tables S1 and S2 in the Supplement). During summer, the phosphorus concentration generally decreased and the nitrogen / phosphorus ratio was higher than the Redfield ratio of 16 (Redfield et al., 1963), suggesting that phosphorus acts as a limiting factor of primary production in the bay. A degradation experiment with phosphate $\left(\mathrm{KH}_{2} \mathrm{PO}_{4}, 2 \mu \mathrm{molL}^{-1}\right)$ was conducted in July 2012 to ensure that phosphorus was not a limiting factor; at this time, the concentration of phosphate was the lowest in the year $\left(0.1 \mu \mathrm{molL}^{-1}\right.$; Tables S1 and S2). The results of the degradation experiment with added phosphorus were not 
significantly different from those of the degradation experiment without added phosphorus $\left(y=1.1 x-8.2, R^{2}=0.97\right.$, $p<0.05$ ). We did not add nutrients for the degradation experiment because we assumed nutrients were not limiting microbial growth.

\subsection{Lability and sources of freshwater DOC flowing into Tokyo Bay}

The lowest chl $a$, DOC, and POC concentrations were observed at the upper Arakawa River station, which is considered to be pristine (Table 1). The average concentration of DOC was $38 \mu \mathrm{molL}^{-1}$ at the upper Arakawa River station. Headstream water sources in Japan are mostly surface runoff from neighboring watersheds and groundwater input which runs through the mineral soil horizon before entering surface water (Nakamura et al., 2011). Precipitation is characterized by very low DOC concentrations (Avery Jr. et al., 2003). Groundwater inputs through the mineral soil horizon typically have low DOC concentrations because mineral soils have the ability to adsorb a significant amount of DOC (Aitkenhead et al., 2003). Such low concentrations of DOC in headstream waters have commonly been reported in Japan (e.g., Maki et al., 2010), as well as in other countries (e.g., Yamashita et al., 2011). The results of the DOC degradation experiments at the upper Arakawa River station are shown in Fig. 2a. Rapid degradation of the labile pool was observed within the first 20 days of incubation. Additionally, the average concentration of RDOC was $25 \mu \mathrm{molL}^{-1}$, which was the lowest value in freshwater and Tokyo Bay sites, and its contribution to the total DOC was $67 \%$.

Relatively high temperatures and DOC values were observed at Shibaura STP, while seasonal variations in chl $a$ and POC were relatively small (Table 1). The average concentration of DOC was $355 \mu \mathrm{molL}^{-1}$, which was about 9 times higher than the value at the upper Arakawa River station. The annual mean concentration of RDOC was $278 \mu \mathrm{mol} \mathrm{L}^{-1}$, while the mean contribution of RDOC to the total DOC was $78 \%$ (Fig. 2b). The RDOC concentrations did not vary greatly between observation months, and a significant linear relationship was observed between BDOC and DOC $\left(R^{2}=0.976, p<0.001\right.$, slope $\left.=1.16\right)$, indicating that the seasonal variations in DOC were mostly due to variations in the bioavailable fraction. Typically, STP effluents have high organic carbon concentrations and a large bioavailable fraction (Servais et al., 1995, 1999; Kaushal and Belt, 2012). In contrast, effluent of Shibaura STP showed a high proportion of RDOC (67-93\%). These findings suggest that most of the BDOC were degraded before being discharged. This likely occurred because STPs in Japan conduct secondary treatment, which consists of the removal of wastewater suspended solids by sedimentation and degradation of dissolved organic matter by activated sludge treatment (Kadlec and Wallace, 2008).
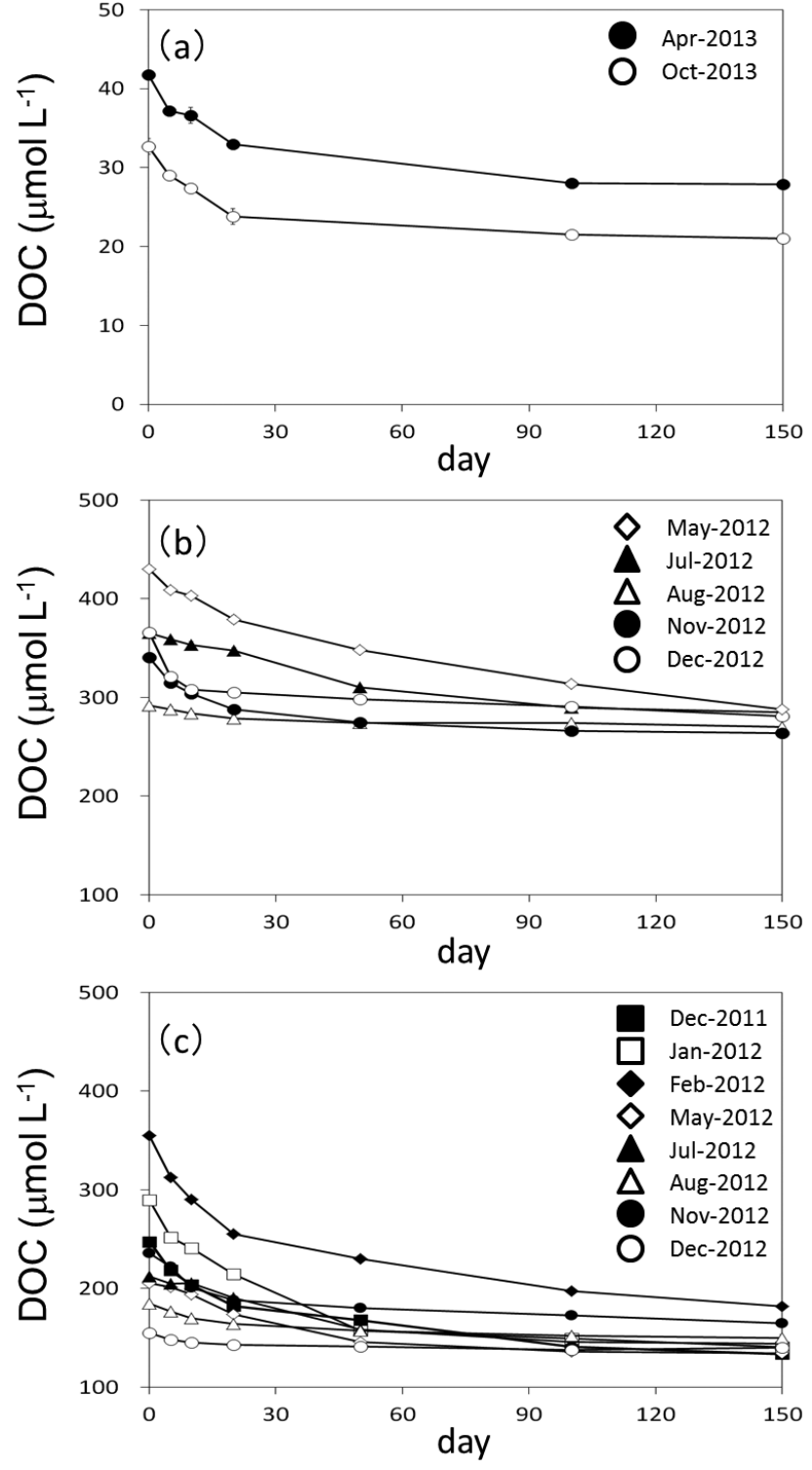

Figure 2. Changes in dissolved organic carbon $\left(\mu \mathrm{molL} \mathrm{L}^{-1}\right)$ in surface water of (a) the upper Arakawa River station, (b) Shibaura STP, and (c) the lower Arakawa River station. Error bars represent the standard deviations.

Relatively high chl $a$ and POC concentrations were observed at the lower Arakawa River station (Table 1). The maximum concentrations of chl $a$, DOC, and POC were observed in spring. The average concentration of DOC was $235 \mu \mathrm{mol} \mathrm{L}{ }^{-1}$, while the annual mean concentration of RDOC was $149 \mu \mathrm{molL}^{-1}$ and the mean contribution of RDOC to the total DOC was $66 \%$ (Fig. 2c). The concentrations of DOC were more than 6 times higher than those at the upper Arakawa River station. High concentrations of nutrients were also observed at the lower Arakawa River station (see Tables S1 and S2), which was likely a result of inputs of DOC and nutrients from STPs between observation sites. 
The RDOC concentrations did not show large differences between observation months, and a significant linear relationship between BDOC and DOC was observed $\left(R^{2}=0.942\right.$, $p<0.001$, slope $=1.12$ ), indicating that the seasonal variations of DOC at the lower Arakawa River station were due to variations in the bioavailable fraction.

Freshwater flowing into Tokyo Bay primarily consists of a mixture of river water and STP effluent. The total discharge ratio of river water to STP effluent in the bay is about $1: 1$ (Japan Sewage Works Association, 2010; Bureau of Sewerage, 2013). Assuming that the ratio of river water to STP effluent is $1: 1$ and that data collected at the upper Arakawa River station and Shibaura STP represent these two sources, the average concentrations of RDOC and BDOC in freshwater would be 152 and $47 \mu \mathrm{mol} \mathrm{L}^{-1}$, respectively. These values are comparable with those observed at the lower Arakawa River station (149 and $86 \mu \mathrm{molL}^{-1}$, respectively). Arakawa River, which is the largest river flowing into the bay, accounts for about $30 \%$ of the freshwater discharge (Nihei et al., 2007a). Most rivers flowing into the bay have similar water quality because of similar land use within the drainage basin (Nihei et al., 2007b); accordingly, we can reasonably assume that observed RDOC and BDOC concentrations at the lower Arakawa River station represent concentrations of total river water flowing into Tokyo Bay.

Table 2 summarizes the first-order decay constants obtained by fitting the exponential degradation of DOC with time. The annual average degradation rate constant normalized to $15^{\circ} \mathrm{C}$ at the lower Arakawa River station was $0.031 \pm 0.005 \mathrm{day}^{-1}$, which was similar to other coastal waters $\left(0.066 \pm 0.065 \mathrm{day}^{-1}\right.$; Lønborg and Álvarez-Salgado, 2012).

\subsection{Tokyo Bay}

Seasonal variations in temperature, salinity, chl $a, \mathrm{POC}$, and $\mathrm{DOC}$ at the three stations in Tokyo Bay are presented in Fig. 3. High values of temperature, chl $a$, POC, and DOC were observed during spring and summer, while low values were observed during autumn and winter. Salinity was higher during autumn and winter than in spring and summer. DOC concentrations ranged from 81 to 182,76 to 153 , and 60 to $108 \mathrm{~mol} \mathrm{~L}^{-1}$ at stations F3, F6, and 06, respectively (Fig. 3). The concentrations of DOC were generally lower than these at the lower Arakawa River station.

\subsubsection{Lability of DOC}

Rapid degradation of the labile pool occurred within the first 20 days of incubation, indicating that BDOCs were remineralized during the residence time of the bay water (Fig. 4). The seasonal variations in DOC, RDOC, and BDOC concentrations at the three stations in Tokyo Bay are shown in Fig. 5. RDOC ranged from 70 to $120 \mu \mathrm{molL}^{-1}$ at F3, 58 to $130 \mu \mathrm{mol} \mathrm{L}^{-1}$ at $\mathrm{F} 6$, and 48 to $80 \mu \mathrm{molL}^{-1}$ at 06 . The
Table 2. Degradation constants for DOC $\left(k_{20}\right)$ and normalized degradation constants at $15^{\circ} \mathrm{C}\left(k_{15}\right) \pm$ standard deviation at the upper Arakawa River (upper AR), the lower Arakawa River (lower AR), and Shibaura STP stations. $R^{2}$ indicates coefficient of determination.

\begin{tabular}{llccc}
\hline Station & Date & $\begin{array}{c}k_{20} \\
\left(\text { day }^{-1}\right)\end{array}$ & $R^{2}$ & $\begin{array}{c}k_{15} \\
\left(\text { day }^{-1}\right)\end{array}$ \\
\hline Upper AR & Apr 2013 & $0.072 \pm 0.006$ & 0.99 & $0.049 \pm 0.004$ \\
Upper AR & Oct 2013 & $0.053 \pm 0.007$ & 0.98 & $0.036 \pm 0.005$ \\
\hline Lower AR & Dec 2011 & $0.038 \pm 0.004$ & 0.97 & $0.025 \pm 0.003$ \\
Lower AR & Jan 2012 & $0.040 \pm 0.004$ & 0.99 & $0.027 \pm 0.003$ \\
Lower AR & Feb 2012 & $0.038 \pm 0.003$ & 0.96 & $0.026 \pm 0.002$ \\
Lower AR & May 2012 & $0.028 \pm 0.004$ & 0.99 & $0.019 \pm 0.003$ \\
Lower AR & Jul 2012 & $0.025 \pm 0.005$ & 0.99 & $0.017 \pm 0.004$ \\
Lower AR & Aug 2012 & $0.045 \pm 0.010$ & 0.99 & $0.031 \pm 0.007$ \\
Lower AR & Nov 2012 & $0.052 \pm 0.005$ & 0.97 & $0.035 \pm 0.004$ \\
Lower AR & Dec 2012 & $0.110 \pm 0.014$ & 0.97 & $0.071 \pm 0.010$ \\
\hline Shibaura STP & May 2012 & $0.019 \pm 0.005$ & 0.99 & $0.013 \pm 0.004$ \\
Shibaura STP & Jul 2012 & $0.021 \pm 0.006$ & 0.99 & $0.014 \pm 0.004$ \\
Shibaura STP & Aug 2012 & $0.040 \pm 0.021$ & 0.97 & $0.027 \pm 0.015$ \\
Shibaura STP & Nov 2012 & $0.062 \pm 0.006$ & 0.99 & $0.042 \pm 0.004$ \\
Shibaura STP & Dec 2012 & $0.110 \pm 0.005$ & 0.92 & $0.072 \pm 0.004$ \\
\hline
\end{tabular}
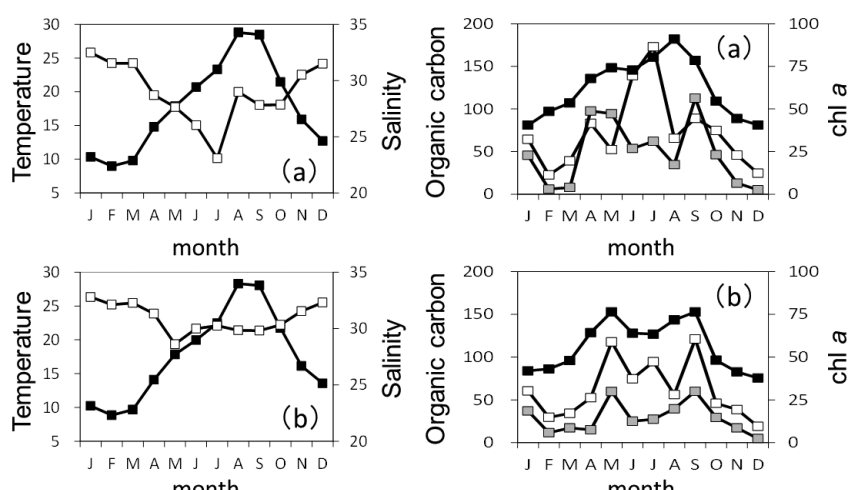

month
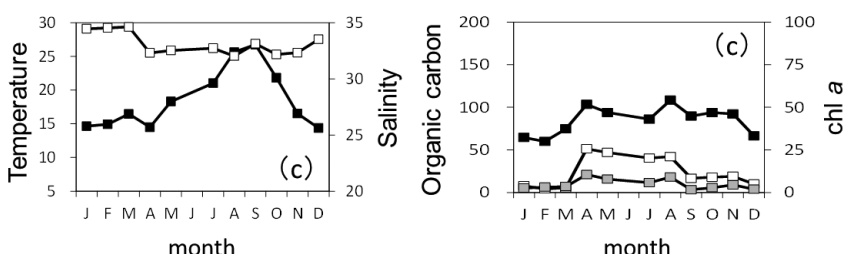

Figure 3. Seasonal variations in salinity (white square), temperature $\left({ }^{\circ} \mathrm{C}\right.$; black square), dissolved organic carbon $\left(\mu \mathrm{mol} \mathrm{L}^{-1}\right.$; black square), particulate organic carbon $\left(\mu \mathrm{molL}^{-1}\right.$; white square), and chlorophyll $a\left(\mu \mathrm{gL}^{-1}\right.$; gray square) at stations (a) F3, (b) F6, and (c) 06 .

mean contributions of RDOC to the total DOC were $81 \%$ at $\mathrm{F} 3,77 \%$ at $\mathrm{F} 6$, and $72 \%$ at 06 . Both RDOC and BDOC showed similar seasonal variations as DOC, with high variations being observed in spring and summer and low variations in autumn and winter. The contribution of RDOC to the total DOC was higher than that of BDOC at all stations for the entire observation period. The RDOC concentrations of the surface water were significantly higher than 

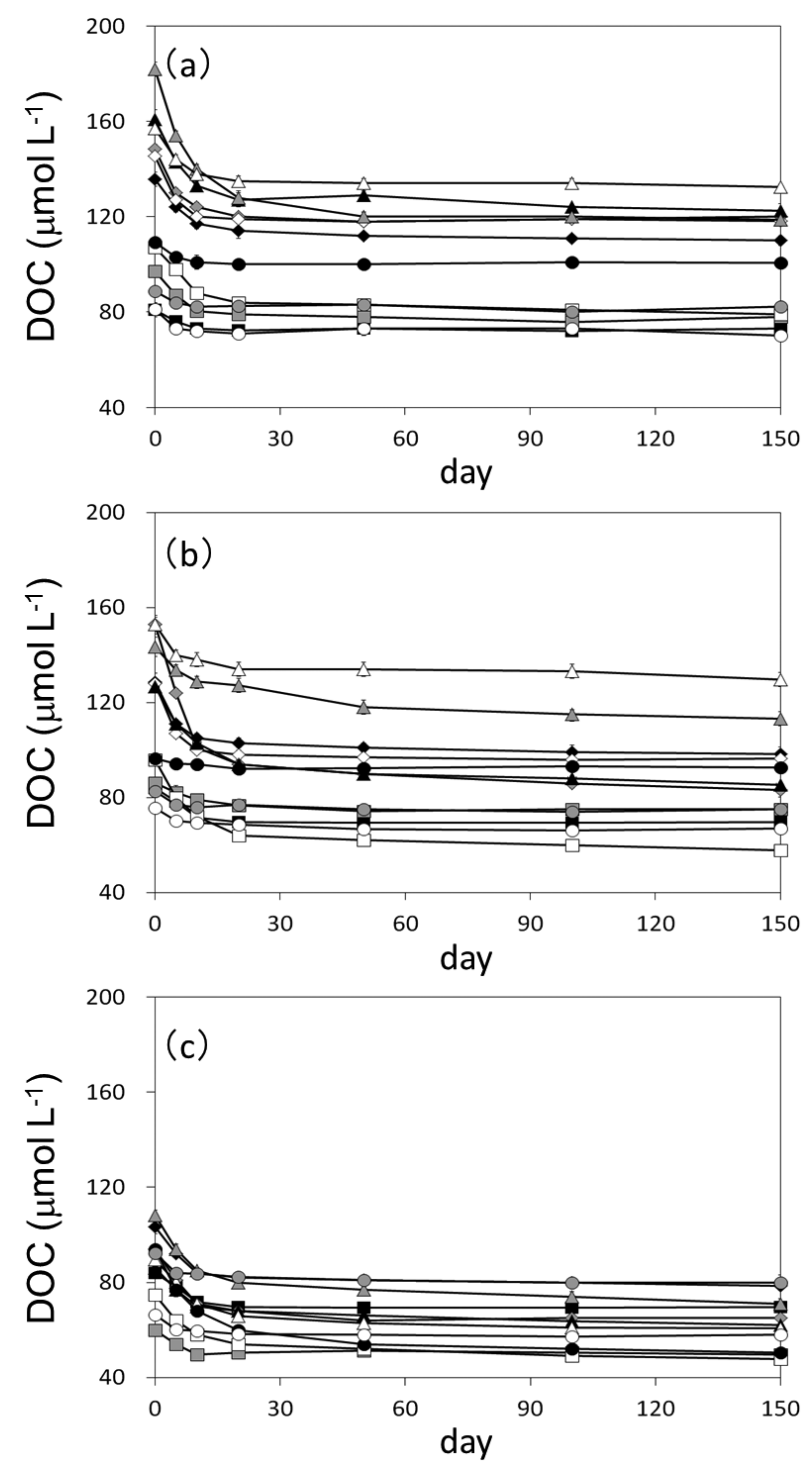

Figure 4. Changes in dissolved organic carbon $\left(\mu \mathrm{mol} \mathrm{L}^{-1}\right)$ in the surface water of stations (a) F3, (b) F6, and (c) 06. Black square: January 2011; gray square: February 2011; white square: March 2011; black diamond: April 2011; gray diamond: May 2011; white diamond: June 2011; black triangle: July 2011; gray triangle: August 2011; white triangle: September 2011; black circle: October 2011; gray circle: November 2011; white circle: December 2011. Error bars represent the standard deviations.

those of the bottom water at 06 (see Table S3 in the Supplement). Thus, our RDOC results likely include a fraction of semi-labile DOC. Degradation of this semi-labile DOC fraction would occur by bacterial mineralization with a longer time span, photodegradation (Moran and Zepp, 1997; Opsahl and Benner, 1997; Obernosterer and Benner, 2004), aggregation (Sholkovitz, 1976; Mulholland, 1981), and/or sorption to particles (Chin et al., 1998; Kerner et al., 2003). However, the results of this study did not change significantly
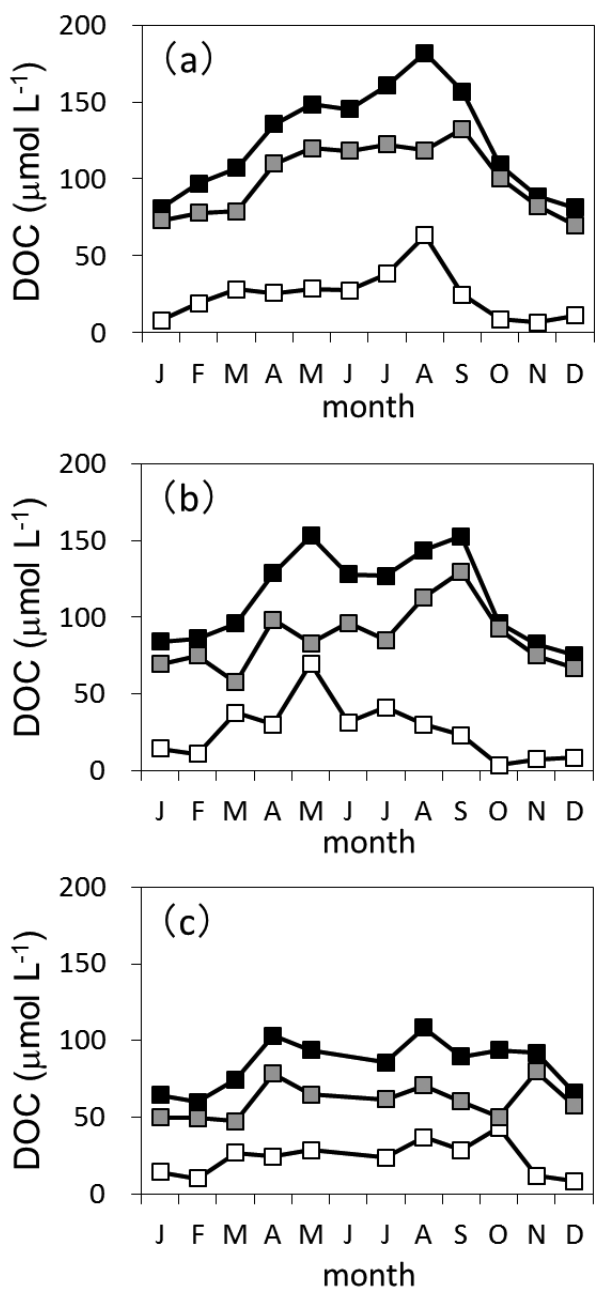

Figure 5. Seasonal variations in DOC (black square), bioavailable DOC (BDOC; white square), and recalcitrant DOC (RDOC; gray square) at stations (a) F3, (b) F6, and (c) 06. Error bars represent the standard deviations.

when DOCs were divided into BDOC, semi-labile DOC, and RDOC. The lifetime of semi-labile DOC is about 1.5 years (Hansell, 2013), which is considerably longer than the residence time of Tokyo Bay (Takada et al., 1992). Therefore, in our analysis, there was no problem with the inclusion of semi-labile DOC in RDOC. In addition, Ogura (1975) only divided DOC into BDOC and RDOC; therefore, we divided DOC in the same way to enable comparison with that study.

Table 3 summarizes the degradation constants of DOC for the bay surface waters. The annual average degradation rate constants normalized to $15^{\circ} \mathrm{C}$ at $\mathrm{F} 3, \mathrm{~F} 6$, and 06 were $0.128 \pm 0.014,0.094 \pm 0.016$, and $0.083 \pm 0.010 \mathrm{day}^{-1}$, respectively. Most degradation rate constants for the bay water were higher than those of freshwater (Table 2). The half-lives of BDOC were calculated from the degradation rate constant. The annual average half-lives of BDOC at F3, F6, and 06 were 5.4, 7.4, and 8.4 days, respectively. BDOC produced 
Table 3. Degradation constants for DOC $\left(k_{20}\right)$ and normalized degradation constants at $15^{\circ} \mathrm{C}\left(k_{15}\right) \pm$ standard deviation in Tokyo Bay (stations F3, F6, and 06). $R^{2}$ indicates coefficient of determination.

\begin{tabular}{|c|c|c|c|c|}
\hline Station & Date & $\begin{array}{c}k_{20} \\
\left(\text { day }^{-1}\right)\end{array}$ & $R^{2}$ & $\begin{array}{c}k_{15} \\
\left(\text { day }^{-1}\right)\end{array}$ \\
\hline F3 & Jan 2012 & $0.236 \pm 0.032$ & 0.98 & $0.159 \pm 0.022$ \\
\hline F3 & Feb 2012 & $.162 \pm 0.012$ & 0.99 & $0.110 \pm 0.008$ \\
\hline F3 & Mar 2012 & $0.093 \pm 0.007$ & 0.97 & $0.063 \pm 0.005$ \\
\hline F3 & Apr 2012 & $0.120 \pm 0.012$ & 0.99 & $0.081 \pm 0.008$ \\
\hline F3 & May 2012 & $0.203 \pm 0.009$ & 0.99 & $0.137 \pm 0.006$ \\
\hline F3 & Jun 2012 & $0.286 \pm 0.007$ & 0.99 & $0.193 \pm 0.005$ \\
\hline F3 & Jul 2012 & $0.127 \pm 0.010$ & 0.97 & $0.086 \pm 0.007$ \\
\hline F3 & Aug 2012 & $0.109 \pm 0.005$ & 0.99 & $0.074 \pm 0.004$ \\
\hline F3 & Sep 2012 & $0.153 \pm 0.010$ & 0.99 & $0.103 \pm 0.007$ \\
\hline F3 & Oct 2012 & $0.301 \pm 0.025$ & 0.98 & $0.203 \pm 0.017$ \\
\hline F3 & Nov 2012 & $0.269 \pm 0.024$ & 0.87 & $0.182 \pm 0.017$ \\
\hline F3 & Dec 2012 & $0.221 \pm 0.019$ & 0.97 & $0.149 \pm 0.014$ \\
\hline F6 & Jan 2012 & $0.150 \pm 0.016$ & 0.98 & $0.101 \pm 0.011$ \\
\hline F6 & 2 & $0.095 \pm$ & 0.99 & 0.06 \\
\hline F6 & Mar 2012 & $0.100 \pm 0.003$ & 0.99 & $0.067 \pm 0.002$ \\
\hline F6 & Apr 2012 & $0.151 \pm 0.011$ & 0.98 & $0.102 \pm 0.008$ \\
\hline F6 & May 2012 & $0.115 \pm 0.005$ & 0.98 & $0.077 \pm 0.004$ \\
\hline F6 & Jun 2012 & $0.209 \pm 0.007$ & 0.99 & $0.141 \pm 0.005$ \\
\hline F6 & Jul 2 & $0.083 \pm 0.006$ & 0.99 & $0.056 \pm 0.004$ \\
\hline F6 & Aug 2012 & $0.050 \pm 0.012$ & 0.97 & $0.033 \pm 0.008$ \\
\hline F6 & Sep 2012 & $0.120 \pm 0.016$ & 0.95 & $0.081 \pm 0.011$ \\
\hline F6 & Oct 2012 & $0.188 \pm 0.054$ & 0.84 & $0.127 \pm 0.040$ \\
\hline F6 & Nov 2012 & $0.243 \pm 0.025$ & 0.91 & $0.164 \pm 0.020$ \\
\hline F6 & Dec 2012 & $0.170 \pm 0.021$ & 0.92 & $0.115 \pm 0.015$ \\
\hline 06 & 2012 & $.043 \pm 0.007$ & 0.94 & $0.029 \pm 0.005$ \\
\hline 06 & Feb 2012 & $0.223 \pm 0.012$ & 0.97 & $0.150 \pm 0.008$ \\
\hline 06 & & $0.091 \pm 0.007$ & 0.98 & \\
\hline 06 & Apr 2012 & $0.133 \pm 0.010$ & 0.99 & $0.089 \pm 0.007$ \\
\hline 06 & May 2012 & $0.134 \pm 0.007$ & 0.99 & $0.090 \pm 0.005$ \\
\hline 06 & Jul 2012 & $0.089 \pm 0.010$ & 0.97 & $0.060 \pm 0.007$ \\
\hline 06 & Aug 2012 & $0.085 \pm 0.006$ & 0.97 & $0.057 \pm 0.004$ \\
\hline 06 & Sep 2012 & $0.094 \pm 0.008$ & 0.99 & $0.063 \pm 0.006$ \\
\hline 06 & Oct 2012 & $0.085 \pm 0.005$ & 0.99 & $0.057 \pm 0.004$ \\
\hline 06 & Nov 2012 & $0.146 \pm 0.021$ & 0.94 & $0.098 \pm 0.014$ \\
\hline 06 & Dec 2012 & $0.240 \pm 0.013$ & 0.87 & $0.162 \pm 0.009$ \\
\hline
\end{tabular}

by phytoplankton in the bay water might have led to faster degradation rates because the half-lives of BDOC were about 5 times faster than the residence time of the bay water.

RDOC concentrations in Tokyo Bay were negatively correlated with salinity and positively correlated with chl $a$ (Table 4). In the bay, salinity was lower in spring and summer than in autumn and winter (Fig. 3) because of high freshwater input during spring and summer. The freshwater RDOC concentration was higher than that of Tokyo Bay water; therefore, a negative relationship between RDOC and salinity was observed. RDOC is also produced directly by phytoplankton (Kragh and Søndergaard, 2009). Hence, the positive relationship between RDOC and chl $a$ observed in this study likely reflected RDOC produced by phytoplankton.
Table 4. Correlation coefficients $\left(R^{2}\right)$ of the significant $(p<0.05)$ linear regressions between DOC and hydrological data in Tokyo Bay (stations F3, F6, 06, and total data). $X$ indicates dependent variable. N.s. indicates not significant.

\begin{tabular}{llll}
\hline Station & $X$ & Salinity & chl $a$ \\
\hline F3 & DOC & 0.54 & 0.36 \\
F3 & RDOC & 0.68 & 0.56 \\
F3 & BDOC & n.s. & n.s. \\
\hline F6 & DOC & 0.74 & 0.64 \\
F6 & RDOC & 0.64 & 0.59 \\
F6 & BDOC & 0.37 & 0.31 \\
\hline 06 & DOC & 0.81 & 0.51 \\
06 & RDOC & 0.54 & 0.47 \\
06 & BDOC & 0.29 & n.s. \\
\hline Total data & DOC & 0.68 & 0.52 \\
Total data & RDOC & 0.73 & 0.62 \\
Total data & BDOC & 0.11 & n.s. \\
\hline
\end{tabular}

\subsubsection{RDOC sources}

To estimate the sources of RDOC in Tokyo Bay, multiple linear regression analysis with salinity and chl $a$ as the independent variables was applied to all RDOC data observed at three stations in Tokyo Bay. BDOC in Tokyo Bay was not well correlated with salinity and chl $a$ (Table 4), so multiple linear regression analysis was not applied to the BDOC data. We obtained the following multiple linear regression equation (Model I):

$$
\begin{gathered}
{[\text { RDOC }]=(259 \pm 38)-(5.96 \pm 1.20) \cdot[\text { Sal }]} \\
+(0.597 \pm 0.20) \cdot[\text { Chl } a] \\
\left(r^{2}=0.79, P<0.001, n=35\right)
\end{gathered}
$$

where $[\mathrm{RDOC}]$ is the RDOC concentration $\left(\mu \mathrm{mol} \mathrm{L}^{-1}\right)$, [Sal] is salinity, and $[\mathrm{Chl} a]$ is the chlorophyll $a$ concentration $\left(\mu \mathrm{gL}^{-1}\right)$ of each sample. The end-member of terrestrial

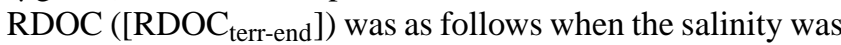
0 :

$\left[\mathrm{RDOC}_{\text {terr-end }}\right]=(259 \pm 38)+(0.597 \pm 0.20) \cdot\left[\mathrm{Chl} a_{\text {river }}\right]$

where [Chl $\left.a_{\text {river }}\right]$ is the chl $a$ concentration $\left(\mu \mathrm{g} \mathrm{L}^{-1}\right)$ at the freshwater site. The end-member of terrestrial RDOC was higher than the average RDOC concentration at the lower Arakawa River station $\left(149 \mu \mathrm{molL}^{-1}\right)$ and was similar to that of Shibaura STP $\left(278 \mu \mathrm{mol} \mathrm{L}^{-1}\right)$. The ratio of river water to STP effluent was 1: 1 (Japan Sewage Works Association, 2010; Bureau of Sewerage, 2013), and data collected at the upper Arakawa River station and Shibaura STP represent these two sources (see Sect. 3.2). It is possible that freshwater inputs into Tokyo Bay were more strongly influenced by STPs than headstream waters. Alternatively, if we assume 
that the RDOC concentration at salinity $=0$ and $\operatorname{chl} a=0$ was close to the average RDOC concentration actually observed at the lower Arakawa River station $\left(149 \mu \mathrm{mol} \mathrm{L}^{-1}\right)$, we obtain the following multiple regression equation (Model II):

$$
\begin{gathered}
{[\mathrm{RDOC}]=149-(2.65 \pm 0.26) \cdot[\mathrm{Sal}]} \\
+(1.03 \pm 0.40) \cdot[\mathrm{Chl} a] \\
\left(r^{2}=0.71, P<0.001, n=35\right)
\end{gathered}
$$

The end-member of terrestrial RDOC ([RDOC terr-end $]$ ) is as follows when salinity is 0 :

$$
\left[\mathrm{RDOC}_{\text {terr-end }}\right]=149+(1.03 \pm 0.40) \cdot\left[\mathrm{Chl} a_{\text {river }}\right]
$$

In this study, we assumed that $\left[\mathrm{Chl} a_{\text {river }}\right]$ was $6.0 \mu \mathrm{g} \mathrm{L}^{-1}$ (Ministry of the Environment: http://www.env.go.jp), which was the average value of surface waters in Arakawa River. Although [Chl $\left.a_{\text {river}}\right]$ is usually lower than $10 \mu \mathrm{g} \mathrm{L}^{-1}$ throughout the year, phytoplankton blooms occasionally persist (Ministry of the Environment: http://www.env.go.jp). The calculation of the RDOC sources using the minimum and maximum chl $a$ concentration at the lower Arakawa River station (Table 1) resulted in estimated RDOC sources that did not differ significantly from the minimum and maximum concentrations.

The concentrations of RDOC in the open ocean

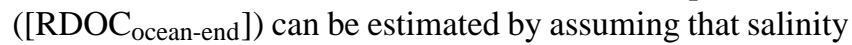
and chl $a$ in the open ocean were 34.5 (Okada et al., 2007) and $1.0 \mu \mathrm{gL}^{-1}$, respectively (Japan Meteorological Agency: http://www.jma.go.jp/jma/index.html), which were the average values of surface waters offshore from Tokyo Bay. The $\left[\mathrm{RDOC}_{\text {ocean-end }}\right]$ values were 54.0 and $58.6 \mu \mathrm{molL}^{-1}$ for Models I and II, respectively, which were comparable to the annual average RDOC concentration of the bottom water at 06 (see Table S3). Following the method described Ogawa and Ogura (1990), we estimated the contributions of RDOC from different sources (RDOC from the open ocean $\left[\mathrm{RDOC}_{\text {ocean origin }}\right]$, terrestrial RDOC $\left[\mathrm{RDOC}_{\text {terr }}\right]$, and RDOC from phytoplankton $\left[\mathrm{RDOC}_{\text {phyto }}\right]$ ), using two models of the multiple linear regression analysis. The RDOC concentrations can be expressed as follows:

$[\mathrm{RDOC}]=\left[\mathrm{RDOC}_{\mathrm{phyto}}\right]+\left[\mathrm{RDOC}_{\mathrm{ocean} \text { origin }}\right]+\left[\mathrm{RDOC}_{\text {terr }}\right]$.

The equation describing RDOC derived from the open ocean

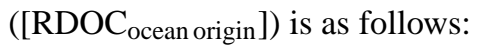

$\left[\mathrm{RDOC}_{\text {ocean origin }}\right]=\left[\mathrm{RDOC}_{\text {ocean-end }}\right] \cdot[\mathrm{Sal}] / 34.5$.

The terrestrial RDOC ([RDOC terr $])$ is as follows:

$\left[\mathrm{RDOC}_{\text {terr }}\right]=\left[\mathrm{RDOC}_{\text {terr-end }}\right] \cdot(34.5-[\mathrm{Sal}]) / 34.5$.

The RDOC derived from phytoplankton ([RDOC phyto $])$ can be estimated from Eq. (7):

$\left[\mathrm{RDOC}_{\mathrm{phyto}}\right]=[\mathrm{RDOC}]-\left[\mathrm{RDOC}_{\mathrm{ocean} \text { origin }}\right]-\left[\mathrm{RDOC}_{\mathrm{terr}}\right]$.
For each multiple linear regression equation (Eqs. 3 and 5), the two-sided $95 \%$ confidence bounds of each coefficient and intercept were estimated. For the concentrations of RDOC originating from phytoplankton, terrestrial, and openoceanic waters, we estimated the upper and lower bounds by changing an equation within its error range. The relative concentrations of RDOC (\%) with error in the bay originating from phytoplankton, terrestrial, and open-oceanic waters at the three stations are presented in Table 5. The results show that the open ocean is the major source of RDOC in Tokyo Bay. At station F3, which is located close to land, terrestrial RDOC was comparable to that from the open ocean. The concentration of terrestrial RDOC was significantly higher than that of RDOC from phytoplankton at all stations, even at the bay mouth.

The influx of terrestrial TOC $(\mathrm{POC}+\mathrm{DOC})$ from the rivers to Tokyo Bay was estimated using a mass balance model $\left(8.1 \times 10^{10} \mathrm{gC} \mathrm{yr}^{-1}\right.$; Yanagi et al., 1993), and the DOC / TOC ratio at the freshwater site was 0.62 (Kubo, unpublished data). Hence, the influx of terrestrial DOC was estimated to be $5.0 \times 10^{10} \mathrm{gCyr}^{-1}$, and RDOC accounted for $66 \%$ of terrestrial DOC (see Sect. 3.2; $3.3 \times$ $10^{10} \mathrm{gC} \mathrm{yr}^{-1}$ ). The efflux of TOC from the surface bay to the open ocean was estimated using a mass balance model $\left(9.4 \times 10^{10} \mathrm{gC} \mathrm{yr}^{-1}\right.$; Yanagi et al., 1993), and the DOC / TOC ratio in the surface bay mouth was 0.69 (Kubo, unpublished data). Hence, the efflux of DOC was estimated to be $6.5 \times 10^{10} \mathrm{gC} \mathrm{yr}^{-1}$, and RDOC accounted for $73 \%$ in the surface bay mouth (see Sect. 3.3; $4.7 \times 10^{10} \mathrm{gC} \mathrm{yr}^{-1}$ ). Assuming that terrestrial and phytoplankton RDOC were exported outside of the bay in the same ratio as at the bay mouth (Table 5), Tokyo Bay exported mostly terrestrial RDOC to the open ocean, owing to the high concentration of terrestrial RDOC and remineralization of BDOC. Moreover, the ratio of terrestrial RDOC input into the bay $\left(3.3 \times 10^{10} \mathrm{gC} \mathrm{yr}^{-1}\right)$ and terrestrial RDOC efflux to the open ocean $\left(0.9 \times 10^{10}\right.$ and $0.6 \times 10^{10} \mathrm{gC} \mathrm{yr}^{-1}$, respectively, for Models I and II) was 28 and $17 \%$, respectively. Residual terrestrial RDOC in the bay may be removed from the water column by photodegradation (Moran and Zepp, 1997; Opsahl and Benner, 1997; Obernosterer and Benner; 2004), aggregation (Sholkovitz, 1976; Mulholland, 1981), and/or sorption to particles (Chin et al., 1998; Kerner et al., 2003).

The fate of terrestrial DOC in the coastal ocean and the open ocean has long been the subject of debate (Hedges et al., 1997). For example, biomarkers (e.g., lignin phenols) and the stable carbon isotopic composition of DOC are commonly used to estimate the contribution of terrestrial DOC to the open ocean (Druffel et al., 1992; Hedges et al., 1997; Raymond and Bauer, 2001; Bauer and Bianchi, 2011). Lignin phenol analysis indicated that terrestrial DOC comprises only a small fraction (4-10\%) of the total DOC in the open ocean (Meyers-Schulte and Hedges, 1986; Opsahl and Benner, 1997; Hernes and Benner, 2006). In addition, the stable carbon isotopic composition of DOC also indicated 
Table 5. Relative concentration of RDOC (\%) \pm error* in Tokyo Bay derived from phytoplankton, terrestrial, and open-oceanic waters, estimated from two multiple linear regressions. ${ }^{*}$ See Sect. 3.3.2.

\begin{tabular}{lccccccc}
\hline Station & \multicolumn{3}{c}{ Model I } & & \multicolumn{3}{c}{ Model II } \\
\cline { 2 - 5 } \cline { 7 - 8 } & Phyto. & Terr. & Ocean & & Phyto. & Terr. & Ocean \\
\hline F3 & $12 \pm 7$ & $42 \pm 3$ & $46 \pm 5$ & & $14 \pm 6$ & $29 \pm 3$ & $57 \pm 4$ \\
F6 & $8 \pm 6$ & $35 \pm 3$ & $57 \pm 5$ & & $10 \pm 6$ & $23 \pm 2$ & $67 \pm 3$ \\
06 & $4 \pm 4$ & $20 \pm 4$ & $76 \pm 4$ & & $5 \pm 4$ & $12 \pm 2$ & $83 \pm 4$ \\
Total data & $8 \pm 6$ & $32 \pm 3$ & $59 \pm 5$ & & $10 \pm 5$ & $21 \pm 3$ & $69 \pm 4$ \\
\hline
\end{tabular}

that terrestrial DOC represents less than $10 \%$ of the total DOC (Bauer et al., 2002). As a result, most terrestrial DOC is remineralized in coastal waters, and only a small fraction is exported to the open ocean. In this study, terrestrial RDOC in the surface bay mouth accounted for less than $20 \%$ of the total RDOC (Table 5). Although these levels were slightly higher than those reported in previous studies using lignin phenols and stable carbon isotopic compositions of DOC, they are probably reasonable given that exported terrestrial RDOC were further diluted with open-oceanic water once outside the bay. Nevertheless, more complete information regarding the sources and lability of DOC are important to enable a better understanding of the fate of DOC in the coastal ocean and open ocean.

\subsection{Change of DOC over 4 decades}

Ogura (1975) investigated the concentrations of RDOC and BDOC in Tokyo Bay and freshwater sources flowing into the bay in the 1970s using GF/C filters (nominal pore size $1.2 \mu \mathrm{m})$ to collect filtrate of degradation samples and found that the contribution of the DOC fraction from $0.45 \mu \mathrm{m}$ (Millipore HA filter, Millipore Corp., Bedford, MA) to $1.2 \mu \mathrm{m}$ was about $10 \%$ of the total DOC in Tokyo Bay. Ogawa and Ogura (1992) also showed that the low-molecular-weight DOC $(<10000$ Dalton; $<0.2 \mu \mathrm{m})$ in the bay comprised a major portion of the total DOC filtered by $1.2 \mu \mathrm{m}(78-97 \%)$. Hence, the DOC fraction from 0.7 to $1.2 \mu \mathrm{m}$ comprised a minor proportion of the DOC in Tokyo Bay. Ogura (1975) used a wet chemical oxidation method to measure the samples, while Ogawa and Ogura (1992) showed that both a wet chemical oxidation method and high-temperature catalytic oxidation method for measuring DOC concentrations of Tokyo Bay waters generated similar results. Ogura (1975) conducted degradation experiments with a short incubation time (about 50 days) compared to our experiment (150 days). However, BDOC can be consumed by bacteria over short periods (days to weeks; Lønborg and Álvarez-Salgado, 2012), and, therefore, the remaining DOC pool after 150 days of incubation, used in Eq. (1), is not significantly different from RDOC concentration at 50 days. Actually, degradation rate constants calculated using data from the first 50 days $\left(k_{50}\right)$ and those using all data from 150 days of experiment $\left(k_{150}\right)$ are not significantly different $\left(k_{50}=0.90 \cdot k_{150}+0.016, R^{2}=\right.$ $0.86, p<0.01)$. Therefore, we assume that our degradation rate constants are comparable to those reported by Ogura (1975).

In 1972, the average concentrations of RDOC and BDOC were 224 and $337 \mu \mathrm{mol} \mathrm{L}{ }^{-1}$ (40 and $60 \%$ of the total DOC, respectively) in the freshwater environment of the lower Tamagawa River, which flows into Tokyo Bay (Ogura, 1975). The present RDOC and BDOC concentrations at the lower Arakawa River station (149 and $\left.86 \mu \mathrm{mol} \mathrm{L}^{-1}\right)$ are lower than those reported by Ogura (1975). If we assumed that the amount of freshwater discharge into the bay has increased by $24 \%$ (Okada et al., 2007), the amount of RDOC and BDOC flowing into the bay would have decreased by 17 and $68 \%$, respectively. Ogura (1975) also estimated a degradation rate constant $\left(k_{15}\right)$ of 0.087 day $^{-1}$, which is much higher than that observed in the present study (Table 2). These changes are consistent with the fact that the proportion of treated wastewater to the total freshwater inflow to the bay increased from 11 to $28 \%$ from 1970 to 2000 (National Institute for Land and Infrastructure Management, 2004). The degradation of DOC at STPs before being discharged should lower the BDOC fraction more than RDOC. Overall, our results indicate that the quantity of DOC flowing into the bay has decreased, and the quality of DOC becomes more recalcitrant.

In Tokyo Bay, the concentrations of DOC at station F3 decreased from $287 \mu \mathrm{mol} \mathrm{L}^{-1}$ in 1972 (Ogura, 1975) to $124 \mu \mathrm{mol} \mathrm{L}^{-1}$ in 2012 , most likely because of a decrease in DOC discharge from rivers and a decrease in primary production (Yamaguchi and Shibata, 1979; Yamaguchi et al., 1991; Bouman et al., 2010). The concentrations of RDOC and BDOC observed in this study (100 and $24 \mu \mathrm{mol} \mathrm{L}{ }^{-1}$, respectively) were lower than those estimated by Ogura (1975) in 1972 (165 and $100 \mu \mathrm{molL}^{-1}$, respectively). Conversely, the contribution of RDOC to the total DOC in this study $(80.6 \%)$ is higher than the value observed in $1972(57.5 \%$; Ogura, 1975). The concentrations of RDOC and BDOC in Tokyo Bay have decreased because of a decrease in DOC load from the land, especially for BDOC. As a result, DOC becomes more recalcitrant. In addition, decreasing nutrient loads in the bay have caused decreasing primary production (Yamaguchi and Shibata, 1979; Yamaguchi et al., 1991; Bouman et al., 2010). Therefore, DOC produced by phytoplankton should also have decreased.

\section{Summary}

Rapid degradation of the labile pool was observed at freshwater sites and Tokyo Bay within the first 20 days of incubation. BDOCs are remineralized during the residence time of the bay water. The contribution of RDOC to the total DOC was higher than that of BDOC at all stations for the entire observation period and accounted for $77 \%$ of the total. 
Accordingly, Tokyo Bay exported mostly terrestrial RDOC to the open ocean owing to the high concentration of terrestrial RDOC and faster half-lives of BDOC relative to the residence time of the bay water. The concentrations of RDOC and BDOC have decreased in the last 40 years at freshwater sites and Tokyo Bay, during which time DOC has become more recalcitrant because of improved sewage treatment. Since organic carbon degradation occurs at STPs before being discharged, DOC flowing into the bay has decreased, especially the BDOC fraction.

\section{The Supplement related to this article is available online at doi:10.5194/bg-12-269-2015-supplement.}

Acknowledgements. We thank Chinatsu Oouchida, as well as other scientists, officers, and crew members on board the R/V Seiyo-maru for their help in sampling. This work was supported by a Grant-in-Aid for Scientific Research (C) (24510009) from the Ministry of Education, Culture, Sports, Science and Technology, Japan, and by a Canon Foundation grant. The authors are grateful to the anonymous reviewers and the associate editor Silvio Pantoja, who provided valuable comments on the manuscript.

Edited by: S. Pantoja

\section{References}

Aitkenhead, J. A., McDowell, W. H., and Neff, J. C.: Sources, production, and regulation of allochthonous dissolved organic matter inputs to surface waters, in: Aquatic Ecosystems: Interactivity of Dissolved Organic Matter, edited by: Findlay, S. E. G. and Sinsabaugh, R. L., Academic Press, San Diego, 25-70, 2003.

Amon, R. M. W. and Benner, R.: Photochemical and microbial consumption of dissolved organic carbon and dissolved oxygen in the Amazon River system, Geochim. Cosmochim. Ac., 60, 17831792, 1996.

Aufdenkampe, A. K., Mayorga, E., Raymond, P. A., Melack, J. M., Doney, S. C., Alin, S. R., Aalto, R. E., and Yoo, K.: Riverine coupling of biogeochemical cycles between land, oceans, and atmosphere, Front. Ecol. Environ., 9, 53-60, 2011.

Avery Jr., G. B., Willey, J. D., Kieber, R. J., Shank, G. C., and Whitehead, R. F.: Flux and bioavailability of Cape Fear River and rainwater dissolved organic carbon to Long Bay, southeastern United States, Global Biogeochem. Cy., 17, 1042, doi:10.1029/2002GB001964, 2003.

Bauer, J. E. and Bianchi, T. S.: Dissolved organic carbon cycling and transformation, in: Treatise on estuarine and coastal science, edited by: Wolanski, E. and McLusky, D. S., Academic Press, Sam Diego, 5, 7-67, 2011.

Bauer, J. E., Druffel, E. R. M., Wolgast, D. M., and Griffin, S.: Temporal and regional variability in sources and cycling of DOC and POC in the northwest Atlantic continental shelf and slope, DeepSea Res. Pt. II, 49, 4387-4419, 2002.
Bouman, H. A., Nakane, T., Oka, K., Nakata, K., Kurita, K., Sathyendranath, S., and Platt, T.: Environmental controls on phytoplankton production in coastal ecosystems: A case study from Tokyo Bay, Estuar. Coast. Shelf S., 87, 63-72, 2010.

Bureau of Sewerage: Management plan 2013, Bureau of Sewerage, Tokyo Metropolitan Government, 117 pp., 2013 (in Japanese).

Carlson, C. A.: Production and removal processes, in: Biogeochemistry of Marine Dissolved Organic Matter, edited by: Hansell, D. A. and Carlson, C. A., Academic Press, San Diego, 91-151, 2002.

Cauwet, G.: DOM in the coastal zone, in: Biogeochemistry of Marine Dissolved Organic Matter, edited by: Hansell, D. A. and Carlson, C. A., Academic Press, San Diego, 579-609, 2002.

Chin, W. C., Orellana, M. V., and Verdugo, P.: Spontaneous assembly of marine dissolved organic matter into polymer gels, Nature, 391, 568-572, 1998.

Cole, J. J., Prairie, Y. T., Caraco, N. F., McDowell, W. H., Tranvik, L. J., Striegl, R. G., Duarte, C. M., Kortelainen, P., Downing, J. A., Middelburg, J. J., and Melack, J.: Plumbing the global carbon cycle: integrating inland waters into the terrestrial carbon budget, Ecosystems, 10, 171-184, 2007.

Dai, M., Yin, Z., Meng, F., Liu, Q., and Cai, W. J.: Spatial distribution of riverine DOC inputs to the ocean: an updated global synthesis, Current Opinion in Environmental Sustainability, 4, 170-178, 2012.

Druffel, E. R. M., Williams, P. M., Bauer, J. E., and Ertel, J. R.: Cycling of dissolved and particulate organic matter in the open ocean, J. Geophys. Res., 97, 15639-15659, 1992.

Hansell, D. A.: Recalcitrant dissolved organic carbon fractions, Annu. Rev. Mar. Sci., 5, 3.1-3.25, 2013.

Hansell, D. A., Carlson, C. A., Repeta, D. J., and Schlitzer, R.: Dissolved organic matter in the ocean: A controversy stimulates new insights, Oceanography, 22, 202-211, 2009.

Hedges, J., Keil, R. G., and Benner, R.: What happens to terrestrial organic matter in the ocean?, Org. Geochem., 27, 195-212, 1997.

Hernes, P. J. and Benner, R.: Terrigenous organic matter sources and reactivity in the North Atlantic Ocean and a comparison to the Arctic and Pacific oceans, Mar. Chem., 100, 66-79, 2006.

Japan Sewage Works Association: Sewage statistics, Japan Sewage Works Association, Tokyo, 2010 (in Japanese).

Kadlec, R. H. and Wallace, S. D.: Treatment wetlands second edition, CRC Press, Boca Raton, Florida, 1000 pp., 2008.

Kaushal, S. S. and Belt, K. T.: The urban watershed continuum: evolving spatial and temporal dimensions, Urban Ecosystems, 15, 409-435, 2012.

Kerner, M., Hohenberg, H., Ertl, S., Reckermann, M., and Spitzy, A.: Self-organization of dissolved organic matter to micelle-like microparticles in river water, Nature, 422, 150-154, 2003.

Kragh, T. and Søndergaard, M.: Production and decomposition of new DOC by marine plankton communities: carbohydrates, refractory components and nutrient limitation, Biogeochemistry, 96, 177-187, 2009.

Lønborg, C. and Álvarez-Salgado, X. A.: Recycling versus export of bioavailable dissolved organic matter in the coastal ocean and efficiency of the continental shelf pump, Global Biogeochem. Cy., 26, GB3018, doi:10.1029/2012GB004353, 2012.

Lønborg, C., Davidson, K., Álvarez-Salgado, X. A., and Miller, A. E. J.: Bioavailability and bacterial degradation rates of 
dissolved organic matter in a temperate coastal area during an annual cycle, Mar. Chem., 113, 219-226, 2009.

Ludwig, W., Probst, J. L., and Kempe, S.: Predicting the oceanic input of organic carbon by continental erosion, Global Biogeochem. Cy., 10, 23-41, 1996.

Maki, K., Kim, C., Yoshimizu, C., Tayasu, I., Miyajima, T., and Nagata, T.: Autochthonous origin of semi-labile dissolved organic carbon in a large monomictic lake (Lake Biwa): carbon stable isotopic evidence, Limnology, 11, 143-153, 2010.

Meybeck, M.: C, N, P and S in rivers: From sources to global inputs, in: Interactions of C, N, P and S Biogeochemical Cycles and Global Change, edited by: Wollast, R., Mackenzie, F. T., and Chou, L., Springer-Verlag, Berlin, 163-193, 1993.

Meyers-Schulte, K. J. and Hedges, J. I.: Molecular evidence for a terrestrial component of organic matter dissolved in ocean water, Nature, 321, 61-63, 1986.

Moran, M. A. and Zepp, R. G.: Role of photoreactions in the formation of biologically labile compounds from dissolved organic matter, Limnol. Oceanogr., 42, 1307-1316, 1997.

Moran, M. A., Sheldon Jr., W. M., and Sheldon, J. E.: Biodegradation of riverine dissolved organic carbon in five estuaries of the southeastern United States, Estuaries, 22, 55-64, 1999.

Mulholland, P. J.: Formation of particulate organic carbon in water from a southeastern swamp-stream, Limnol. Oceanogr., 26, 790795, 1981

Nakamura, T., Osaka, K., Hiraga, Y., and Kazama, F.: Nitrogen and oxygen isotope composition of nitrate in stream water of Fuji River basin, J. Jpn. Assoc. Hydrol. Sci., 41, 79-89, 2011 (in Japanese with English abstract).

National Institute for Land and Infrastructure Management: Information of port environment, 2004, available at: http://www.nilim. go.jp/, last access: 25 June 2013.

Nellemann, C., Hain, S., and Alder, J.: Rapid response assessment in dead water: Merging of climate change with pollution, overharvest, and infestations in the world's fishing grounds, United Nations Environment Programme, 61 pp., 2008.

Nihei, Y., Takamura, T., and Watanabe, N.: Issues on discharge monitoring in main influence rivers into Tokyo Bay, Journal of JSCE, 54, 1226-1230, 2007a (in Japanese with English abstract).

Nihei, Y., Ehara, K., Usuda, M., Sakai, A., and Shigeta, K.: Water quality and pollutant load in the Edo River, Ara River and Tama River, Journal of JSCE, 54, 1221-1225, 2007b (in Japanese with English abstract).

Obernosterer, I. and Benner, R.: Competition between biological and photochemical processes in the mineralization of dissolved organic carbon, Limnol. Oceanogr., 49, 117-124, 2004.

Ogawa, H. and Ogura, N.: Source and behavior of organic carbon of seawater in Tokyo Bay, Chikyukagaku, 24, 27-41, 1990 (in Japanese with English abstract).

Ogawa, H. and Ogura, N.: Comparison of two methods for measuring dissolved organic carbon in sea water, Nature, 356, 696-698, 1992.

Ogura, N.: Further studies on decomposition of dissolved organic matter in coastal seawater, Mar. Biol., 31, 101-111, 1975.

Okada, T., Takao, T., Nakayama, K., and Furukawa, K.: Change in freshwater discharge and residence time of seawater in Tokyo Bay, Journal of JSCE, 63, 67-72, 2007 (in Japanese with English abstract).
Opsahl, S. and Benner, R.: Distribution and cycling of terrigenous dissolved organic matter in the ocean, Nature, 386, 480-482, 1997.

Raymond, P. A. and Bauer, J. E.: Bacterial consumption of DOC during transport through a temperate estuary, Aquat. Microb. Ecol., 22, 1-12, 2000.

Raymond, P. A. and Bauer, J. E.: Riverine export of aged terrestrial organic matter to the North Atlantic Ocean, Nature, 409, 497500, 2001.

Redfield, A. C., Ketchum, B. H., and Richards, F. A.: The influence of organisms on the composition of sea-water, in: The Sea, edited by: Hill, M. N., Interscience, New York, 26-77, 1963.

Regnier, P., Friedlingstein, P., Ciais, P., Mackenzie, F. T., Gruber, N., Janssens, I. A., Laruelle, G. G., Lauerwald, R., Luyssaert, S., Andersson, A. J., Arndt, S., Arnosti, C., Borges, A. V., Dale, A. W., Gallego-Sala, A., Goddéris, Y., Goossens, N., Hartmann, J., Heinze, C., Ilyina, T., Joos, F., LaRowe, D. E., Leifeld, J., Meysman, F. J. R., Munhoven, G., Raymond, P. A., Spahni, R., Suntharalingam, P., and Thullner, M.: Anthropogenic perturbation of the carbon fluxes from land to ocean, Nat. Geosci., 6, 597-607, 2013.

Servais, P., Barillier, A., and Garnier, J.: Determination of the biodegradable fraction of dissolved and particulate organic carbon in waters, Ann. Limnol.-Int. J. Lim., 31, 75-80, 1995.

Servais, P., Garnier, J., Demarteau, N., Brion, N., and Billen, G.: Supply of organic matter and bacteria to aquatic ecosystems through waste water effluents, Water Res., 33, 3521-3531, 1999.

Sholkovitz, E. R.: Flocculation of dissolved organic and inorganic matter during the mixing of river water and seawater, Geochim. Cosmochim. Ac., 40, 831-845, 1976.

Suzuki, R. and Ishimaru, T.: An improved method for the determination of phytoplankton chlorophyll using $\mathrm{N}, \mathrm{N}$ Dimethylformamide, Journal of the Oceanographical Society of Japan, 46, 190-194, 1990.

Takada, H., Ishiwatari, R., and Ogura, N.: Distribution of linear alkylbenzenes (LABs) and linear alkylbenzene sulphonates (LAS) in Tokyo Bay sediments, Estuar. Coast. Shelf S., 35, 141156, 1992.

Tanaka, Y., Ogawa, H., and Miyajima, T.: Production and bacterial decomposition of dissolved organic matter in a fringing coral reef, J. Oceanogr., 67, 427-437, 2011.

Tranvik, L. and Höfle, M. G.: Bacterial growth in mixed cultures on dissolved organic carbon from humic and clear waters, Appl. Environ. Microb., 53, 482-488, 1987.

Yamaguchi, Y. and Shibata, Y.: Recent status of primary production in Tokyo Bay, Bull. Coast. Oceanogr., 16, 106-111, 1979 (in Japanese).

Yamaguchi, Y., Satoh, H., and Aruga, Y.: Seasonal changes of organic carbon and nitrogen production by phytoplankton in the estuary of river Tamagawa, Mar. Pollut. Bull., 23, 723-725, 1991.

Yamashita, Y., Kloeppel, B. D., Knoepp, J., Zausen, G. L., and Jaffé, R.: Effect of watershed history on dissolved organic matter characteristics in headwater streams, Ecosystems, 14, 1110-1122, 2011.

Yanagi, T., Saino, T., Ishimaru, T., and Uye, S.: A carbon budget in Tokyo Bay, J. Oceanogr., 49, 249-256, 1993. 